\title{
BUSINESS STRATEGY AND CORPORATE RESPONSIBILITY: PERCEPTION AND PRACTICE IN THE OIL INDUSTRY AND THE ROLE OF NON-GOVERNMENTAL ORGANISATIONS
}

\author{
Asad K. GHALIB ${ }^{1}$, Patricia AGUPUSI ${ }^{2}$ \\ ${ }^{1}$ Liverpool Hope Business School, Liverpool Hope University, UK and Brooks World Poverty \\ Institute, School of Environment, Education and Development, University of Manchester, \\ Oxford Road, Manchester, UK \\ ${ }^{2}$ Watson Institute for International Studies, Brown University, USA \\ E-mails: ${ }^{2}$ ghaliba@hope.ac.uk (correspondingauthor); ${ }^{2}$ patricia_agupusi@brown.edu
}

Received 19 December 2011; accepted 07 August 2012

\begin{abstract}
This paper examines the strategies for the implementation of corporate social responsibility of various multinationals, with a particular focus on the oil industry. The role of non-governmental organisations towards inducing a more responsible behaviour is explored. By drawing on literature and reflecting on documented actions of various multinational corporations, particularly from the extractive sector, we find a commonalty that cuts across the board: a considerable disparity exists between policies, strategies and actions that these organisations display in the interest of their inherent, short-term economic gains. Such gains jeopardize interests of both internal and external stakeholders as well as the environment especially in the developing world. We argue that the disparity in implementation can be linked to weak structural institutions and lack of ethical standards in most developing countries.
\end{abstract}

Keywords: corporate social responsibility, business strategy, non-governmental organisations, developing countries, oil industry.

JEL Classification: M14, O15, Q34, Q56, R11.

\section{Introduction}

The turn of the century has witnessed a momentous growth in the corporate world. This has brought about dramatic changes to the way people live and how societies and economies operate and interact. As a consequence, there have been unprecedented implications on ecosystems and the environment. Multinational corporations (MNCs) have today infiltrated our lives to an extent beyond which there is no recourse. Over the years, however, there has been an increasing pressure on them to clean up their act and behave more responsibly towards the planet and its people. Corporate social responsibility (CSR) has been hailed by many as an effective way by which these commercial giants will think and behave more conscientiously and thus have a positive impact on countless individuals, societies and the environment. 
Expressions such as corporate responsibility, corporate citizenship, good corporate governance, and "the ethical corporation" have today become mainstream terms in development thinking. Mazurkiewicz (2004) states that although the concept has been evolving since the early 1970s, there is no single, commonly accepted definition of CSR. Instead, there are different perceptions of the concept amongst the private sector, governments, and civil society organizations. Depending on the perspective, CSR may cover three main areas: first, a company running its business responsibly in relation to internal stakeholders (shareholders, employees, customers and suppliers); second, the role of businesses in relationship to the state, locally and nationally, as well as business role to inter-state institutions, and third, CSR business performance as a responsible member of the society in which it operates in the global community (ibid.). The EU's Green Paper (2001: 6) states that "being socially responsible means not only fulfilling legal expectations, but also going beyond compliance and investing "more" into human capital, the environment and the relations with stakeholders". Baker (2007: 1) describes it simply as "a concept about how companies manage the business processes to produce an overall positive impact on society". Waddock $(2004,2006)$ comes up with an even simpler description: the deliberate efforts that companies make to improve society.

Sadly, our findings which we discuss in the sections that follow reveal that in strong contrast to the definitions put forth, MNCs do not appear to invest in human capital or the environment. Furthermore, they do not seem to be making a positive impact on the society at large. We draw on instances originating from the corporate behaviour of companies involved in the oil industry, particularly those based in the developing world to investigate how they comply with the principles and ethics of being responsible to all stakeholders.

Following this brief introduction, section one discusses the drivers of corporate responsibility, while section two explores its strategic dimensions. Prior to concluding, section three explores organisational dilemmas relating to CSR with a particular emphasis on the extractive industry by using cases of Shell and Rio Tinto as illustrations.

\section{The drivers of corporate responsibility}

According to Carroll (1983: 604) "CSR involves the conduct of a business so that it is economically profitable, law abiding, ethical and socially supportive. To be socially responsible then means that profitability and obedience to the law are foremost conditions when discussing the firm's ethics and the extent to which it supports the society in which it exists with contributions of money, time and talent. Thus, CSR comprises four parts: economic, legal, ethical and voluntary or philanthropic". Carroll (1991) represents the concept in a pyramid and as shown in Figure 1, states that such sequencing "helps the manager to see that the different types of obligations are in a constant tension with one another".

What drives organisations to be responsible? The internet, as well as print and electronic news media in today's global economy, has resulted in an information revolution that places business practices around the world under constant spotlight. Consequently, 


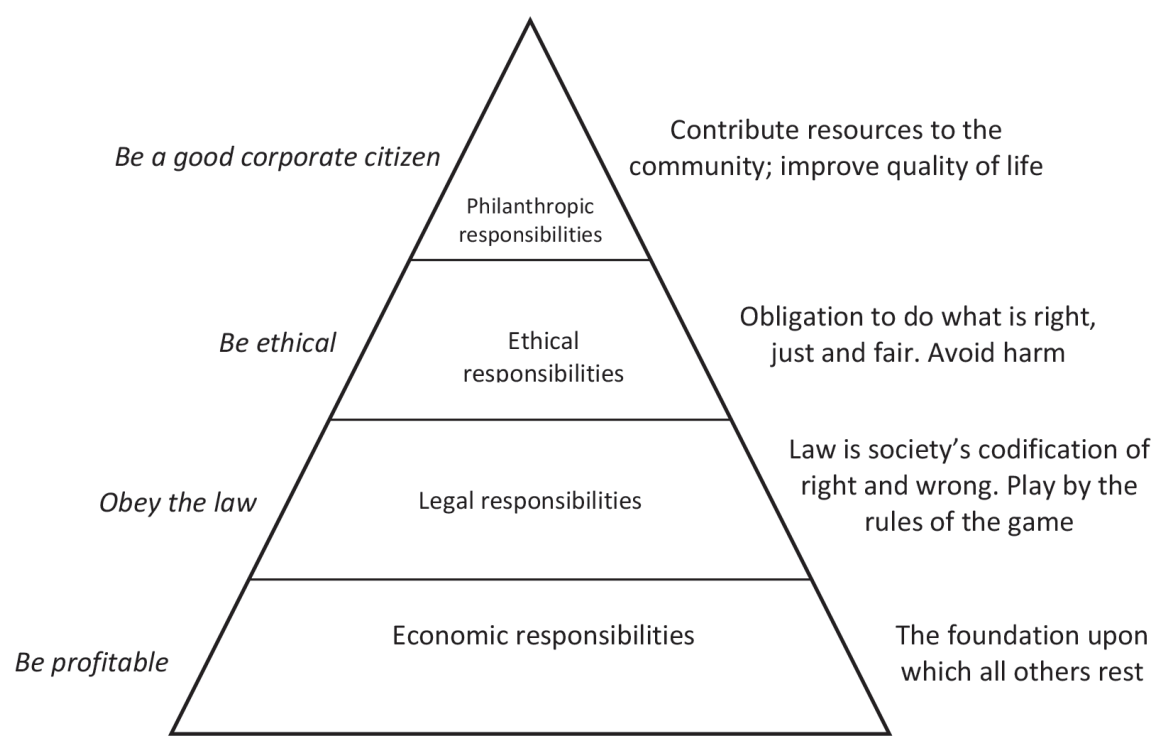

Fig. 1. Carroll's (1991) pyramid of corporate social responsibility

organisations are increasingly being judged on the basis of their social and environmental stewardship. Stakeholders at various levels want to know what goes on inside a company as well as the management's priorities and practices. They want to do business with companies in which they can trust and believe. Hence, this transparency of business practices means that for many companies, CSR is no longer a luxury but a requirement (Mazurkiewicz 2004: 2).

Essentially, the drivers of CSR comprise a mix of incentives and risks directed at companies to improve operating standards. These drivers, as shown in Table 1, according to Mazurkiewicz (2004) are market-based, usually beginning when a firm anticipates or responds to a risk associated with the social, labour or environmental impact of a specific business practice. Mazurkiewicz identifies three fundamental types of drivers: economic, social and political.

Economic drivers, as explained by Mazurkiewicz, are geared primarily towards factors that are more materialistic and quantifiable, such as the company's image and

Table 1. The drivers of corporate social responsibility

\begin{tabular}{|c|c|c|}
\hline Economic drivers & Social drivers & Political drivers \\
\hline $\begin{array}{l}\text { Company image/reputation } \\
\text { Improved risk management } \\
\text { Competitive advantage } \\
\text { Pressure from business partners } \\
\text { Pressure from costumers } \\
\text { Pressure from investors } \\
\text { Competitiveness }\end{array}$ & $\begin{array}{l}\text { Pressure from } \mathrm{NGO} / \mathrm{CSOs} \\
\text { License to operate } \\
\text { Pressure from local } \\
\text { communities } \\
\text { Research }\end{array}$ & $\begin{array}{l}\text { Improved standing with } \\
\text { government } \\
\text { Legal, regulatory drivers } \\
\text { Political pressure } \\
\text { License to operate }\end{array}$ \\
\hline
\end{tabular}


reputation; pressures faced from external stakeholders such as competitors, customers, and investors. Competitiveness is another economic driver that plays a vital role in shaping a company's strategy towards effective policy formulation. However, these could be seen as secondary compared to the primary economic driver which is profit given that the primary aim of the aforementioned drivers is to maximise profit. Social drivers are more focused on pressures faced from third sector organizations, watchdogs, NGOs, activists and local communities. Since the very concept of CSR pertains to social thinking and is meant to benefit individuals, societies and communities, social drivers play a very central role in shaping any organization's strategy and approach towards designing its CSR policy. However, it is the political drivers that would determine the extent to which a company would comply with its CSR policy. This is because political drivers originate from legal and regulatory frameworks imposed by governments and also due to the pressures faced by way of political forces that come into play.

\section{Corporate social responsibility and strategic management}

Strategic management is a process that encompasses an integrated future-oriented managerial perspective that is outwardly focused, forward-thinking and performance-based (Kiggundu 1996). CSR, as seen above, could benefit both the society and the environment. The results are far-reaching and go beyond mere individuals and localities and encompass entire societies and communities. The question that arises is how and why should organisations be motivated to invest in enough resources to achieve such goals? The internal and external measures in effective policy formulation discussed above addressed some of these. Here, we look at how organizations tend to serve their own strategic business interests, while striving to comply with regulations and at the same time, serve the stakeholders and the environment.

"Corporate social responsibility (policy, program or process)", according to Burke and Logsdon (1996: 496) "is strategic when it yields substantial business-related benefits to the firm, in particular by supporting core business activities and thus contributing to the firm's effectiveness in accomplishing its mission". The authors have identified five dimensions of corporate strategy which they state to be both critical to the success of the firm and useful in relating CSR policies, programs and processes to value creation. These are: centrality, specificity, proactivity, voluntarism and visibility. As shown in Figure 2, value creation is the outcome that firms strive to achieve by means of strategic management. These dimensions have been briefly described below.

Centrality measures the "closeness of fit between a CSR program and the firm's mission and objectives" (ibid). It enables the management to continuously check if its strategies are in-line with the firm's overall objectives as it tends to act as a feedback mechanism. An example of centrality may be the millions of dollars spent by car manufacturers in research and development each year to design engines that are more efficient in fuel economy and also cut $\mathrm{CO}_{2}$ emissions. Specificity refers to the firm's ability to capture or 


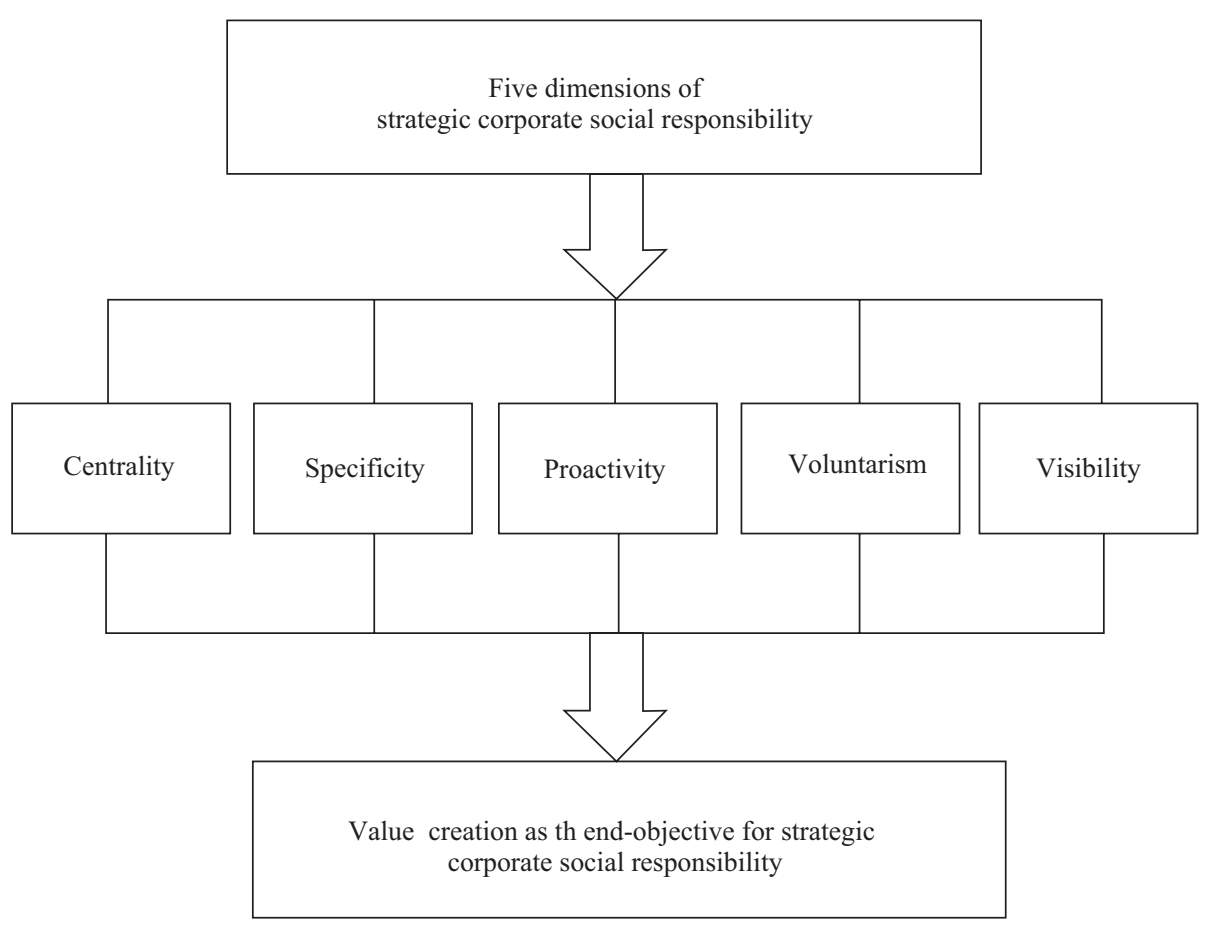

Fig. 2. The five dimensions of CSR and value creation as the intended outcome Source: Authors' construct.

internalize the benefits of a CSR program, rather than simply creating collective goods which can be shared by others in the industry. "Proactivity reflects the degree to which activity is planned in anticipation of emerging economic, technological, social or political trends and in the absence of crisis conditions. Proactivity has long been identified by business strategists as an important characteristic of planning and scanning systems" (Burke, Logsdon 1996: 498). Voluntarism has been described as the "scope of discretionary decision-making by the firm and the absence of externally-imposed compliance requirements" (ibid.). Finally, visibility signifies the extent to which an organization gains observation and recognition from both internal and external stakeholders due to any form of business activity. The activity in question may be either deliberate (aimed at getting a positive visibility) or accidental (resulting in negative visibility). Table 2 provides a number of examples of potentially strategic CSR activities. The benefits which they offer are listed in the last column.

\section{Being socially irresponsible at the corporate level - the case of Royal Dutch Shell PLC, Rio Tinto and other multinationals}

Being socially responsible does not mean merely fulfilling legal requirements, donating to local charities and funding a couple of philanthropic projects. It comprises developing 


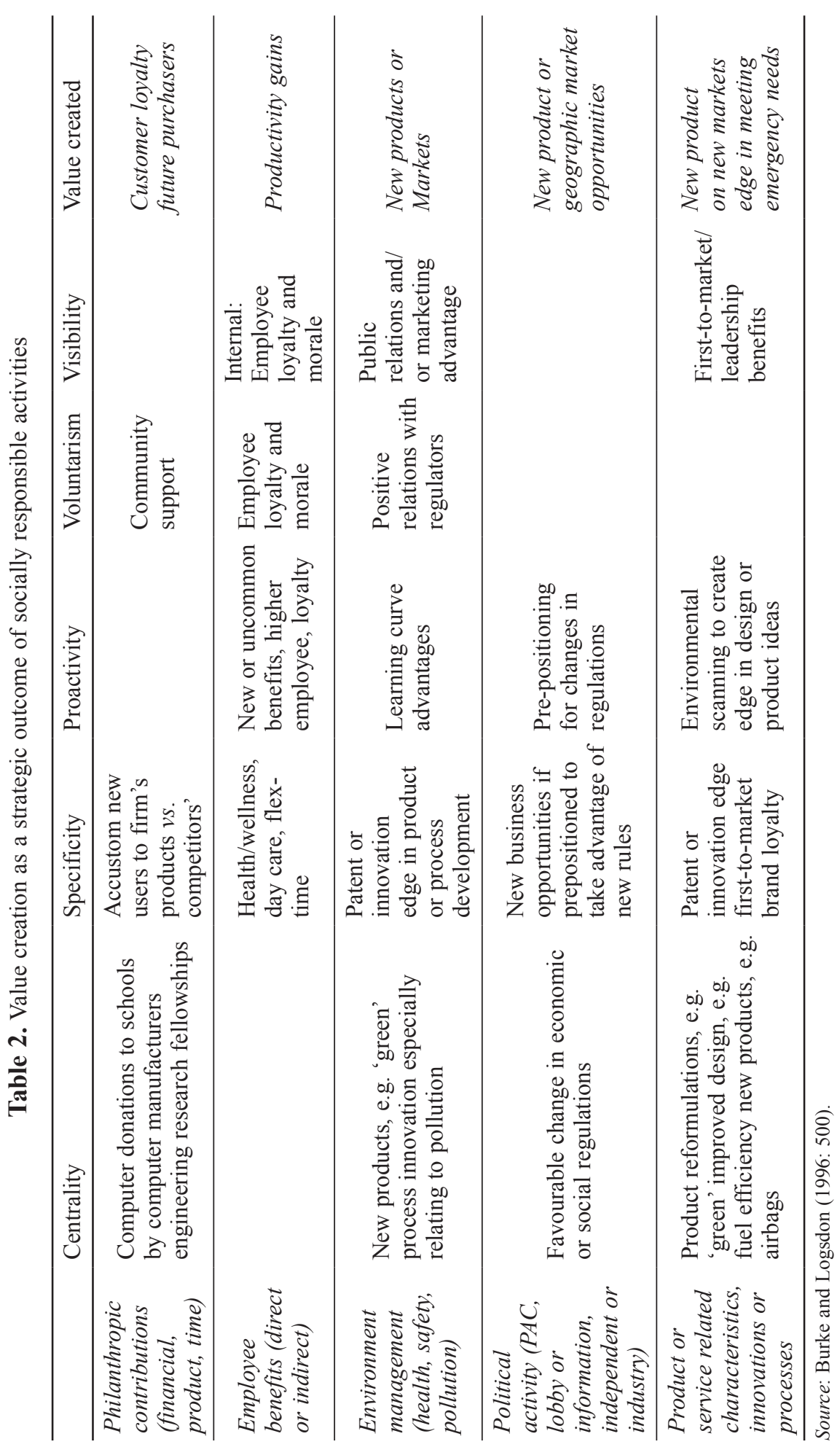


human capital, promoting and assisting development of the company and society, and taking solid measures to protect the environment. Only such deliberate and sincere efforts lead to building affable relations with stakeholders, both internal and external. Unfortunately, many corporate giants do not practice what they preach, especially in developing countries. Enormous pressures of tough competition lead them to take certain measures that jeopardize their responsibility as a corporate citizen in the global society. We will take the oil industry as an example. Within the extractive sector, the oil business is well-known to be rife with corruption, pollution and violation of human rights, especially where huge corporate giants drill oil in developing countries. Let us consider Shell's operations in the Niger-Delta region of Nigeria, West Africa and mining company of Rio Tinto in Indonesia.

According to the U.S. Energy Information Administration (EIA 2013), Nigeria is the largest oil producer in Africa and was the world's fourth leading exporter of LNG in 2012. Despite the billions raised in revenue each year, a majority of the population in the oil-rich Niger-Delta live in absolute poverty. Their livelihoods once depended predominantly on fishing and farming in and around the fertile river networks of the delta region that have been considerably destroyed. Today, these waters are heavily polluted with floating oil and the entire ecosystem has been destroyed due to acid-rain. Cases such as oil leakage, gas flaring, forest destruction, waste dumping, soil damage and water pollution affect communities at a phenomenal extent (Kamalu et al. 2002; Bloemink, de Clerck 2000). Consequently, hunger and desperation ultimately lead to extreme measures, such as theft of oil pipelines and the oil itself by tapping into the thousands of kilometres of pipelines that crisscross the Niger-Delta. Stolen oil pipes are sold as scrap metal and oil is used as fuel for cooking or selling on the black market. Unfortunately, such incidences end tragically in fires breaking out, and to-date thousands had perished in accidents. According to data compiled by the BBC (2006) relating to fire-related deaths during the past few years, over three thousand people have perished and many more have been injured, the worst such disaster being the tragic fire that broke out in the oilfields at Jesse in 1998 in which over 1,000 were killed.

Shell is the largest oil company operating in Nigeria. Its global revenues of $\$ 368$ billion and profits of $\$ 18.6$ billion in 2010 made it the second-largest corporation in the world by revenues and profitability (BBC 2010). The magnitude of its operations make it a subject of particular scrutiny by stakeholders, especially environmental and human rights groups and local communities. This makes it all the more important for such companies to have a very effective and robust CSR policy. Shell's General Business Principles (2010: 3) state that they will:

“...respect the human rights of our employees and conduct business as responsible corporate members of society, to comply with applicable laws and regulations, to support fundamental human rights in line with the legitimate role of business, and to give proper regard to health, safety, security and the environment...".

Ironically, it has been involved in a series of violations and has been in the media constantly over the past few years on matters relating to human rights violation, corruption and damage to the environment. In 2006, Nigeria's Federal High Court ordered Shell 
to pay a fine of $\$ 1.5$ billion for environmental damage to the homeland of the Ijaws in the Niger-Delta. Shell refused to pay the fine claiming that it remains in the belief that it has strong grounds to appeal the compensation order. It has said that much of the environmental damage in the Niger-Delta was caused by saboteurs and reversed its data from 98 to 70 per cent after Amnesty International published an alternative report (Donovan 2013). In January 2013, a Dutch court ruled that Shell's Nigeria subsidiary was responsible for oil pollution in Niger-Delta and ordered to pay damages. Although this is a step in the right direction, the court also exonerated Shell from four others including oil spills (Sekularac, Deutsch 2013). This is in sharp contrast to that of the April 2010 Deepwater Horizon BP oil spill in the Gulf of Mexico which was seen as a national disaster in the USA and led to a media frenzy all over the world. Through pressure from the US government, BP created a \$20 billion response fund apart from paying more than $\$ 75$ million for the clean-up.

During 2002 in the Delta region in Nigeria, fourteen individual plaintiffs filed an action on the grounds that Shell violated international law and engaged in militarised commerce in a conspiracy with the former military government of Nigeria. The suit argued that Shell knowingly "instigated, planned, facilitated, and participated in unprovoked attacks by the Nigerian military against the unarmed residents of Ogoniland, resulting in extrajudicial murder, crimes against humanity, torture, rape, cruel, inhuman and degrading treatment, arbitrary arrest and detention, forced exile and the deliberate destruction of private property" (Business Respect 2002). A UK-based NGO Friends of the Earth published an "alternative Shell report" called "Lessons Not Learned", the third alternative Shell report which catalogues how despite commitments made in previous years, Shell still exhibits total disregard for the rights of the people living near its operations in many parts of the world. Shell responded with a robust riposte, disputing a number of claims made by the group (Friends of the Earth 2005).

Despite the millions that the company pumps into local economies worldwide to fund and support it's socially responsible and "green" projects, it still continues to trample human rights and ignores rights of indigenous people. For a company that reportedly earned nearly \$1.6 million per hour (Macalister 2011), it becomes very difficult to comprehend why it has continually failed the local communities, and why it continues to destroy the environment in which it operates. Sadly, despite extensive media coverage and public outcry in several parts of the world, Shell continues to vehemently deny any wrongdoing and continues its operations as ever. Estimated figures for Shell alone for carbon emissions in 2005 were $102 \mathrm{~m}$ tones - more than what 150 countries produce collectively (Macalister 2007). The magnitude and scale of the pollution such as carbon emissions can only be guessed if the joint estimates of the three major companies (Shell, $\mathrm{BP}$ and ExxonMobil) are taken together.

Another case is that of Texaco oil dumping in Ecuador forest and spill to Amazon River. Texaco which was in operation of an oil concession in Ecuador since 1964 until its merger with Chevron in 2001 discharged waste oil far more larger than the Gulf Oil spill according to report. The oil discharged has contaminated Amazon River and contributed to high rise of cancer and other skin diseases in the region. According to New 
York Times of May 2009 report, the toxic chemicals leaked into the soil, groundwater and stream are poisoning to the indigenous children and affecting their livelihoods. As a result, Chevron was taken to court by the indigenous people of Ecuador mostly affected by these activities. The court cases including $\$ 27$ billion in damages for dumping more 345 million gallons of crude oil in the rainforest and 18.5 gallons of toxic waste in pits in the forest (Khor 2010). These cases were linked to what the indigenous groups called environmental discrimination by Texaco citing 1996 minority discrimination lawsuit which was settled for \$176 million (Souter 1999). Despite the settlement, Texaco maintained they have acted responsibly and have used standard industry practice and there is lack of scientific evidence to support the claim (Talbot 1999).

For lack of legal precedent in Ecuador, the case was filed in the USA using the Alien Claims Tort Act of 1770 which was enacted by the congress in 1980s (Markels 1999). The case was initially dismissed in 1996 but was overturned by the appeal court decision. The lack of legal institution in Ecuador posed a problem and a major challenge for Ecuador. It also echoes similar challenges in other developing countries with weak or no system to enforce corporate social responsibility. The case which has been transformed to Chevron verses Ecuador tribe continues. In 2008, the US Congressman James P. McGovern, the vice-chairman of the House Rules Committee, visited Ecuador and reported in a letter to Obama that "the degradation and contamination left behind by Chevron in a poor part of the world made me angry and ashamed... I also saw the infrastructure Texaco/Chevron created that allowed the wholesale dumping of formation water and other highly toxic materials directly into the Amazon and its waters" (McGovern 2008).

The debate of the double standard by Multinational operations in the developing countries continues but the question remains, what are the developing countries doing to reduce the irresponsibility of multinationals in developing countries? This is because in some cases state officials enable $\mathrm{MNC}$ in unethical activities and to avoid their responsibilities.

Let us consider the case of Rio Tinto, a British Australian company which is one of the largest mining companies in the world and is known for its several accolades as an ethical and environment-friendly company. In 2007, it was awarded the Corporate Social Responsibility Award and also the Nedbank Environmental Award. With these awards, one wonders what Rio Tinto could do wrong in its CSR activities. Despite such CSR awards, Rio Tinto's operations have been less attractive in a lot of countries ranging from South Africa to the USA. Let us take Indonesia, one of their 35 countries as an example.

In West Papua, Rio Tinto in joint venture with Freeport McMoRan, was accused of causing massive environmental destruction due to the dumping of toxic waste metals into the Indonesian river system. The dumping polluted the river and lead to loss of means of livelihood and source of clean water by local communities. Also, Rio Tinto forcefully evicted the community from their land with people's assets destroyed during the construction of the mine. It was reported by the Indonesian Human Rights Commission that protesters were arrested and detained and in some instances, people were 
shot while local police ran campaigns to squash the protest (Curtis 2007). Rio Tinto's partner Freeport-McMoRon exploited the system by providing financial support to the military police and the government to ensure protection of the mine. The reality is that the multinationals are not alone in this type of destructive activities as in some cases government acts as accomplish. For example, Rio Tinto disagreed that the riverine disposal is expressly prohibited under Indonesia's water quality control regulation. The company argues that "this programme was approved by the government of Indonesia following numerous technical studies to identify the appropriate tailings management plan for the site". This is part of factors that distinct the activities from developed to developing countries.

Compare the incident in Indonesia to that of Boron community in the USA where action was taken against the company by the small miners who were disfranchised by the company. The community was able to mobilize support not only from the people but the State of California and the US government to fight for a fair contract. In a country like Indonesia the company got the support of the government while in the USA, the community got the support of the government. So although the operation and activities might be similar across countries, consequences differ.

The above discussion indicates that corporations to a large extent, take their corporate strategic implementations seriously and where they are "caught out", are held responsible for their actions. However, while this might be the case in developed countries the contrast is glaring in developing countries. Examples discussed above where legal actions were taken successfully against unethical activities of corporations occurred in developed countries while legal action is hardly brought against corporations in most developing countries and even if taken, the corporations still get away with their irresponsible actions as seen with the case of Shell's activities in Nigeria as compared to the BP oil spill in the USA. Additionally, product recalls which have been carried out by several corporations, occurred only in developed countries. The question is why do corporations attempt to act responsibly in some regions and irresponsibly in others?

Lack of consensus on conceptualising CSR strategy is argued by some as one of the reasons it is not visible in the developing countries. For example, Visser (2005) suggests that values-based traditional philosophy of African humanism is what underpins much of the modern inclusive approaches to CSR on the continent. However, Schmidheiny (2006) argues that it is important for businesses to recognise socio-economic needs of a particular locality rather than importing foreign strategies. Locally developed CSR approaches are more likely to respond to the many social and environmental problems in the region, such as alternative means of livelihoods, provision of social infrastructure and job creation as in the case of the people of Niger Delta whose means of livelihoods have been destroyed due to oil exploration (De Oliveira 2006). Michael Spicer argues that "having CSR guided by the socio-economic priorities of the country or region is simply a good business" (Visser 2007: 11).

The poor impact of CSR strategies in developing countries could be attributed to factors such as asymmetrical power relations between the state, host communities and businesses interests. Moreover, lack of or weak institutions to enforce CSR strategies 
and unethical culture of host countries that collaborate with and allow businesses to get away with unethical practices mitigate CSR strategies implementation in the developing world. Consequently, multinationals utilise and manipulate loopholes and structural weaknesses of key systems (political, economic and social) in these countries. This explains why some multinationals could easily get away with substantial ethical abuse, such as years of oil spills in the Niger-Delta.

\section{Concluding remarks: the future of CSR and the role of NGOs}

The case of the extractive sector in general, and Shell in particular along with other cases in the preceding section highlight the reality of many large corporations pledging to be socially responsible, yet acting otherwise. Integrating corporate social responsibility into its core policy, acts as a long-term strategic investment, such as investing in human capital formation and building local communities. Since most of the companies tend to forget or neglect the social responsibilities and are inclined to focus on the revenues that they expect to acquire, NGOs are faced with the responsibility of community advocacies. They play a vital part to remind businesses of their roles in the society and to follow the rules of the government and preserve the environment. Thus, community advocacy is an essential part of NGOs activities (Kelly 2002).

The concept of the "Non-Governmental Organization" has matured well over the years which have witnessed a sudden surge in their formation, formalization and recognition on a global scale. They operate individually and collectively at all levels of society and have an impact on many aspects of peoples' lives, ranging from their political and civil rights and obligations, to economic, social and cultural rights and opportunities. The International Institute for Sustainable Development (IISD 2007: 1) reiterates the powerful role that NGOs play in today's globalised economy:

"NGOs have helped to focus attention on the social and environmental externalities of business activity. Multinational brands have been acutely susceptible to pressure from activists and from NGOs eager to challenge a company's labour, environmental or human rights record".

The report goes on to state that due to such pressures, many businesses have been seen to abandon their Milton Friedmanite shareholder theory of value in favour of a broader, stakeholder approach. Such moves not only seek increased share value, but also tend to consider how such increased value can be attained.

Although some CSR strategies are driven by genuine intentions to be responsible, to operate more conscientiously and thus have a positive impact on the stakeholders, societies and the environment; many MNCs' CSR strategies have not been proactive enough in implementing their policies in developing countries. This consequently leads to an obvious contrast in implementation of such responsible strategies in developed and developing countries despite the influence of NGOs and the media. Hence, in reality, business implementation of CSR strategies depends largely on the region as well as a country's structural strength and accountability of its institutions, the presence and role of NGOs and the general awareness of its people. 


\section{References}

Baker, M. 2007. Corporate Social Responsibility - What does it mean? [online], [cited 4 April 2011]. Available from Internet: http://www.mallenbaker.net/csr/definition.php

BBC News (Africa). 2006. Lagos Pipeline Blast Kills Scores, 26 December 2006, 20:44 GMT [online], [cited 11 April 2011]. Available from Internet: http://news.bbc.co.uk/2/hi/ africa/6209845.stm

BBC. 2010. Royal Dutch Shell Profits up 50\% on Oil Price, 28 April 2010 [online]. Available from Internet: http://news.bbc.co.uk/1/hi/8648091.stm

Bloemink, I.; de Clerck, P. 2000. Victims of their own fortunes: ongoing environmental problems resulting from oil production in the Niger Delta in Nigeria. The Netherlands, Amsterdam: Milieudefensie.

Burke, L.; Logsdon, J. M. 1996. How corporate social responsibility pays off, Long Range Planning 29: 495-502. http://dx.doi.org/10.1016/0024-6301(96)00041-6

Business Respect. 2002. Shell Hit by New Litigation Over Ogoniland [online], [cited 10 April 2011]. Available from Internet: http://businessrespect.net/page.php?Story_ID $=616$

Carroll, A. B. 1983. Corporate social responsibility: will industry respond to cut-backs in social program funding?, Vital Speeches of the Day 49: 604-608.

Carroll, A. B. 1991. The pyramid of corporate social responsibility: toward the moral management organizational stakeholders, Business Horizons 34: 39-48.

http://dx.doi.org/10.1016/0007-6813(91)90005-G

Curtis, M. 2007. Fanning the flames: the role of British mining companies in conflict and the violation of human rights. London: War on Want, Development House.

De Oliveira, J. A. P. 2006. Corporate citizenship in Latin America: new challenges to business, Journal of Corporate Citizenship 21(spring): 17-20.

Donovan, J. 2013. Shell Oil Spillage in Niger Delta up 70 Percent in 2012 [online], [cited 25 April 2013]. Available from Internet: http://royaldutchshellplc.com/2013/01/24/shell-oil-spillagein-niger-delta-up-70-percent-in-2012/

EIA 2013. Nigeria: Country Analysis Brief Overview [online]. U.S. Energy Information Administration, Washington, DC. Available from Internet: http://www.eia.gov/countries/country-data. cfm?fips $=$ ni

European Union. 2001. Promoting a European framework for corporate social responsibility: Green Paper. Directorate-General for Employment and Social Affairs. Office for Official Publications of the European Communities, European Commission, Luxembourg.

Friends of the Earth. 2005. Lessons Not Learned. The Other Shell Report 2004. London, 26-28.

Kamalu, O. J.; Isirimah, N. O.; Ugwa, I. K.; Orimoloye, J. R. 2002. Evaluating the characteristics of the meander belt soils of the Niger-Delta, South Eastern Nigeria, Singapore Journal of Tropical Geography 23(2): 207-216. http://dx.doi.org/10.1111/1467-9493.00125

Kelly, L. 2002. International advocacy: measuring performance and effectiveness. Australia: Praxis Consultants Ptd Ltd.

Khor, K. 2010. The double standards of multinationals, The Guardian, 25 June 2010, 10.00 BST [online]. Available from Internet: http://www.guardian.co.uk/commentisfree/cif-green/2010/ jun/25/double-standards-multinationals-ecological-disasters

Kiggundu, M. N. 1996. Integrating strategic management tasks into implementing agencies: from fire-fighting to prevention, World Development 24(9): 1417-1430.

http://dx.doi.org/10.1016/0305-750X(96)00055-1 
IISD. 2007. The Rise and Role of NGOs in Sustainable Development, Business and Sustainable Development: a Global Guide [online], [cited 9 April 2011]. Available from Internet: http://www.iisd.org/business/ngo/roles.asp

Macalister, T. 2011. Shell makes nearly £1.6m profits every hour, The Guardian, 3 February 2011 [online], [cited 10 April 2011]. Available from Internet: http://www.guardian.co.uk/business/2011/ feb/03/shell-profits-nearly-one-point-six-million-an-hour

Macalister, T. 2007. Profits up a Fifth but Shell Emits More $\mathrm{CO}_{2}$ than Most Countries [online], [cited 28 April 2013]. Available from Internet: http://www.guardian.co.uk/business/2007/feb/02/ oilandpetrol.climatechange

Mazurkiewicz, P. 2004. Corporate Environmental Responsibility: Is a Common CSR Framework Possible? (Unpublished Paper).

Markels, A.1999. Texacos crude legacy, Mother Jones 1999(May): 64.

McGovern, J. P. 2008. Letter to Barack Obama, president elect, 17 November 2008 [online]. Available from Internet: http://mcgovern.house.gov/uploads/Scan001.PDF

Schmidheiny, S. 2006. A view of corporate citizenship in Latin America, Journal of Corporate Citizenship 21(spring): 21-24.

Sekularac, I.; Deutsch, A. 2013. Dutch court says Shell responsible for Nigeria spills, The Hague, 30 January 2013. Reuters [online], [cited 23 April 2013]. Available from Internet:

http://uk.reuters.com/article/2013/01/30/uk-shell-nigeria-lawsuit-idUKBRE90T0DC20130130

Shell Foundation. 2003. Origins and Relationships [online]. Available from Internet: http://www.shellfoundation.org/images/origins/Shel_Foundation_origins.pdf

Shell International Limited. 2010. General Business Principles [online]. Available from Intermet: http://www.static.shell.com/static/aboutshell/downloads/who_we_are/sgbps/sgbp_english.pdf

Souter, G. 1999. Campaign charges Texaco with racism. Business Insurance 4 October 1999.

Talbot, D. 1999. Rain forest pays the price of oil; suit claims Texaco polluted Ecuador, The Boston Herald, 29 August 1999: News.

Visser, W. 2005. Is South Africa world class in corporate citizenship?, in A. Freemantle (Ed.). The good corporate citizen. Johannesburg: Trialogue.

Visser, W. 2007. Revisiting Carroll's CSR Pyramid, in Crane and Matten.

Waddock, S. 2004. Parallel universes: companies, academics, and the progress of corporate citizenship, Business and Society Review 109: 5-42. http://dx.doi.org/10.1111/j.0045-3609.2004.00002.x Waddock, S. 2006. Leading corporate citizens: vision, values, value added. 2nd ed. New York: McGraw-Hill.

Asad K. GHALIB, Dr, is a Lecturer at the Liverpool Hope Business School, Liverpool Hope University and an External Research Associate at the Brooks World Poverty Institute, School of Environment, Education and Development at The University of Manchester, UK. He has previously held positions with a number of international organisations around the world in the development, research, not-forprofit, financial and banking services industry.

Patricia AGUPUSI, Dr, is a Postdoctoral Fellow at Watson Institute for International Studies, Brown University, USA. Her research includes theories of inequality, political economy of institutional development and governance. She just concluded a book manuscript that investigates "homegrown" development initiatives in Africa that have been put in place between 1990 and 2009, focusing specifically on Ghana, Nigeria, South Africa and Kenya. 